\title{
Konsep OVOP Untuk Mengidentifikasi Produk Unggulan Daerah (Studi Kasus Wajik Tapai Melayu)
}

\author{
Sri Maryanti*1, Nining Sudiar ${ }^{2}$, Afred $\mathrm{Suci}^{3}$, Hardi ${ }^{4}$ \\ Universitas Lancang Kuning: Jln. Yos Sudarso KM.8 Rumbai Pekanbaru, Telpon, (0761)52581 \\ ${ }^{1}$ Fakultas Ekonomi, ${ }^{2}$ Fakultas Ilmu Budaya, Universitas Lancang Kuning \\ E-mail: ssrimaryanti@yahoo.com
}

\begin{abstract}
Abstrak
Dalam penelitian ini digunakan One Village One Product (OVOP) yang bertujuan untuk menganalisis pembangunan daerah dengan tujuan memajukan ekonomi suatu daerah melalui identifikasi produk unggulan yang ada didaerah tersebut. Adapun tujuan menggunakan One Village One Product (OVOP) adalah untuk mengidentifikasi terhadap produk unggulan daerah, mengidentifikasi potensi pasar dan mengidentifikasi strategi pengembangan produk unggulan daerah menggunakan analisia SWOT terhadap produk pangan Wajik Tapai Melayu. Hasil dari penelitian ini adalah ada beberapa produk yang bisa dijadikan produk unggulan daerah di Riau salah satunya adalah produk pangan Wajik Tapai Melayu. Hal ini juga didukung oleh Pemerintah Propinsi Riau saat ini mencanangkan pengembangan objek wisata di Riau untuk menarik wisatawan untuk berkunjung ke Riau, dengan meningkatnya wisatawan ke Riau akan berdampak terhadap pertumbuhan industri kecil salah satunya produk pangan Wajik Tape Melayu yang juga menjadi Produk Unggulan Daerah di Riau.
\end{abstract}

Kata Kunci: Produk Unggulan Daerah, Wajik Tape Melayu Riau, Analisis SWOT, One Village One Product (OVOP)

\begin{abstract}
In this research, One Village One Product $(O V O P)$ is used to evaluate regional development with the objective of promoting the economy of the region through the identification of superior products in the region. The aim of One Village One Product (OVOP) is to define regionally superior products, to identify market potential and to define regionally superior product development policies using a SWOT analysis of Wajik Tapai Melayu food products. The findings of this research are that there are several products that can be used as regional superior products in Riau, one of which is Wajik Tapai Malaya food products. This is also endorsed by the Riau Provincial Government, which is presently promoting the creation of tourist attractions in Riau to attract visitors to Riau, with the rise in visitors to Riau having an effect on the growth of tiny sectors, one of which is the Malay Food Tape food product, which is also the Riau Regional Leading Product.
\end{abstract}

Keyword: Regional Flagship Products, Riau Malay Diamond Wajik, SWOT Analysis, One Village One Product (OVOP)

\section{PENDAHULUAN}

Provinsi Riau memiliki potensi sumber daya dan merupakan wilayah yang menjadi tujuan para pendatang untuk membuka lapangan usaha dan mencari pekerjaan, disamping itu Provinsi Riau saat ini juga menjadi tujuan destinasi wisata bagi pendatang karena potensi ekonomi Provinsi Riau sangat berkembang dan tingginya daya saing ekonomi daerah. Saat ini telah banyak tempat-tempat tujuan wisata yang mulai dibangun oleh Pemerintah Provinsi Riau terkait dicanangkannya pengembangan objek wisata. Hal ini tentu jadi peluang bagi Provinsi Riau untuk mengembangkan produk-produk makanan menjadi unggulan daerah Provinsi Riau salah satunya adalah Wajik Tapai Melayu. Usaha Wajik Tapai Melayu ini merupakan Icon dari Provinsi Riau selain Sagu, disamping itu Wajik Tapai Melayu merupakan satu-satunya produk yang terbuat dari tapai sehingga produk ini menjadi unik. 
Wajik Tapai Melayu dijadikan sebagai produk unggulan daerah karena memenuhi beberapa indikator suatu produk dapat dijadikan sebagai unggulan daerah seperti yang tertuang dalam Peraturan Mentri Dalam Negeri No 9 Tahun 2014 tentang Pedoman Pengembangan Produk Unggulan Daerah yaitu:

(a) Mempunyai daya saing yang tinggi di pasaran ( keunikan/ ciri spesifik, kualitas bagus , harga murah)

(b) Memanfaatkan potensi sumberdaya lokal yang potensial untuk dikembangkan

(c) Mempunyai nilai tambah yang tinggi bagi masyarkat pedesaan

(d) Secra ekonomi menguntungkan dan bermanfaat untuk meningkatkan pendapatan dan kemampuan sumberdaya manusia

(e) Layak didukung oleh bantuan modal dan kredit

Terkait dengan hal diatas saat ini produk pangan yang ada di Riau berasal dari beberapa daerah bahakan dari luar negeri sehingga masyarakat setempat dan para pendatang pun sulit untuk mengetahui produk apa saja yang menjadi unggulan daerah Provinsi Riau. Jika di Sumatera Barat banyak produk yang merupakan produk unggulan daerah tersebut sebut saja keripik sanjai yang telah sampai ke mancanegara seperti Singapura dengan produk keripik balado dari Kristin Hakim dan masih banyak lagi yang menjadi unggulan daerah tersebut. Melihat hal tersebut tentu hal ini menjadi pemikiran bagi kita, sebenarnya apa saja produk pangan yang menjadi unggulan daerah di Riau ini. Melalui fenomena tersebut maka dilakukan pengidentifikasian melalui pendekatan One Village One Product (OVOP) atau "satu desa satu produk" telah lama dikembangkan hal ini merupakan upaya untuk meningkatkan daya saing suatu produk unggulan daerah sehingga produk suatu daerah mampu bersaing dengan produk yang ada, untuk pengembangkan potensi suatu desa mejadi lebih maju, dapat menghasilkan produk yang memiliki ciri khass disuatu daerah dengan memanfaatkan sumber daya lokal. agar setiap produk yang ada dihasilkan di Riau mampu dikembangkan dan berdaya saing tinggi.

Adapun tujuan dari pengembangan produk unggulan daerah melalui pendekatan OVOP yaitu: (Muhammad Tommy Fimi Putera,2015:108)

1. Melakukan pemasaran produk unggulan daerah dalam skala lokal maupun internasional

2. Meningkatkan kualitas produk agar meiliki daya saing sehingga dapat mendorong inovasi, semangat kebersamaan dan pengembangan skill

3. Meningkatkan nilai tambah suatu produk serta mengembangkannya agar mampu bersaing dengan produk luar negeri (impor)

4. Meningkatkan income bagi masyarakat setempat

Jika diperhatikan produk pangan Wajik Tapai Melayu telah lama dirintis sejak tahun 2008, produk ini telah memiliki pangsa pasar yang sangat luas mulai dari dalam wialayah Kota Pekanbaru sendiri sampai merambah pasar luar dari Kota Pekanbaru. Produk pangan yang satu ini sangat unik dan satu-satunya produk wajik yang berbahan dasar tapai. Jika produk sejenis seperti dodol hanya berbahan dasar tepung ketan dan gula tanpa ada penambahan produk lainnya yang menjadi unsur utamanya. Keunikkan inilah yang menjadikan Wajik Tapai Melayu telah memiliki pangsa pasar tersendiri sehingga produk pangan ini tidak mematikan usaha dari produk-produk sejenisnya. Namun yang menjadi kendalanya adalah apakah Wajik tapai Melayu ini benar-benar telah menjadi produk unggulan daerah di Riau? Oleh karena itu melalui pendekatan OVOP ini akan dilakukan identifikasi produk unggulan daerah pada Wajik Tapai Melayu.

\section{METODE}

Jenis penelitian ini adalah penelitian desktiptif kualitatif, yang bertujuan untuk membuat deskripsi atau gambaran secara sistematis, faktual dan akurat mengenai fakta-fakta, sifat-sifat serta hubungan antara fenomena yang diteliti serta untuk mengetahui sejauhmana indicator pendung dari produk unggulan daerah tersebut bisa di identifikasi pada produk Wajik tapai Melayu.

Dalam penelitian ini melibatkan tiga fihak sebagai informan yaitu pemerintah, tenaga ahli dan masyarakat itu sendiri. Disamping itu fihak Wajik Tapai Melayu juga terlibat dalam kegiatan 
penelitian ini yang berjumlah 10 orang yang diambil dengan teknik purposive sampling, teknik ini dipilih untuk menggali informasi mengenai pengembangan produk unggulan daerah untuk produk pangan yang bersumber dari ahlinya. Data yang digunakan dalam penelitian ini dikumpulkan melalui teknik wawancara.

Analisa data yang digunakan adalah analisis SWOT yang dilakukan utnuk menganalisis factor-faktor internal dan eksternal pihak pengusaha dalam pengembangan produk pangan sehingga diketahui apa saja factor yang emnadji kekauatn dan kelemahan, serta peluang dan ancaman yang dihadapi dalam rangka meningkatkan daya daing untuk produk pangan lainnya. Dari hasil analisis SWOT diperoleh beberapa alternative strategi untuk mengembangkan produk pangan menjadi produk unggulan daerah di Riau.

\section{HASIL DAN PEMBAHASAN}

\section{Identifikasi Produk Unggulan daerah}

Berdasarkan Peraturan Mentri Dalam Negeri No 9 Tahun 2014 dan Juknis Dirjen IKM Nomor 98/IKM/PER/9/2013 ada beberapa kriteria suatu produk bisa digolongkan sebagai unggulan daerah berdasarkan kriteria OVOP yaitu produk makanan, minuman, kain, anyaman, keramik/gerabah. Berdasarkan hasil penelitian diperoleh beberapa kriteria yang bisa digolongkan dalam beberapa kalsifikasi yang menunjukkan kualitas dari produk tersebut.

Kualisifikasi tergolong kualitas sangat baik dan memenuhi untuk pasar ekspor akan memenuhi skor 91-100

Kualisifikasi tergolong kualitas baik dan memenuhi untuk pasar dalam negeri/ nasional memenuhi skor 81 - 90

Kualisifikasi tergolong kualitas cukup baik dengan beberapa perbaikan untukn memenuhi untuk pasar nasional/dalam negeri akan memenuhi skor $71-80$

Kualisifikasi tergolong kualitas perlu bimbingan dasar namun bisa mencapai pada skor 7180 dengan memenuhi skor $61-70$

Kualisifikasi tergolong kualitas banyak kelemahan dan sulit untuk dikembangkan dalam waktu dekat jika hanya memenuhi skor $50-60$

Tabel 1: Skoring rata-Rata Tertimbang dan Kasifikasi OVOP Produk Wajik Tapai Melayu dan Produk Pangan Lainnya Sebagai Produk Unggulan daerah di Provinsi Riau

\begin{tabular}{lcc}
\hline \multirow{2}{*}{ Produk } & \multicolumn{2}{c}{ Kriteria OVOP } \\
\cline { 2 - 3 } & Skor & Klas \\
\hline Makanan Ringan & 70 & Perlu bimbingan \\
\hline Wajik Tapai Melayu & 89 & Kualitas baik \\
\hline Batik & 80 & Cukup baik \\
\hline \multicolumn{2}{c}{ Sumber : Data Olahan Kriteria OVOP } &
\end{tabular}

Jika dilihat dari table diatas terlihat bahwa produk makanan ringan yang ada di Riau masih perlu bimbingan untuk menjadi produk unggulan daerah, sedangkan untuk produk Wajik Tapai Melayu tergolong berluakitas baik dan mampu menembus pasar dalam negeri sedangkan untuk produk Batik Riau masih dikategorikan cukup baik hal ini dilihat dari permintaan akan produk Batik riau yang dinilai masih belum sepopuler batik dari daerah jawa.

\section{Analisis SWOT (Strenght, Weakness, Opportunity \& Threat)}

Dengan kajian ini maka masih perlu dilakukan strategi-strategi untuk menjadikan produk yang lain menjadi produk unggulan daerah yaitu melihat mengevaluasi kekuatan, kelemahan, peluang dan ancaman dari suatu produk dalam hal ini produk Wajik Tapai Melayu. Proses berawal dari penentuan tujuan spesifik dan spekulasi usaha serta mengidentifikasi factor internal dan eksternal yang mendukung dan tidak tercapainya tujuan tersebut. 
Adapun strategi yang harus dilakukan adalah:

1. Meningkatkan keunikkan dan kekhassan muatan lokal

2. Melakukan kerjasama dengan pemerintah daerah, perusahaan-perusahaan untuk menjadikan produk yang dihasilkan sebagai produk unggulan atau sebagai oleh-oleh

3. Terus melakukan promosi untuk tiap produk yang dihasilkan

4. Melakukan diskusi atau dengar pendapat dari pemilik usaha yang berada pada skor baik agar produk yang dihasilkan bisa meningkatkan kualitas produknya

5. Menjalin kerjasama produksi, pemasarandengan para pengrajin yang sukses

6. Meningkatkan skill dan kemapuan mengolah produk berbahan baku local

7. Meningkatkan kemampuan manajemen dan motivasi usaha

8. Meningkatkan peluang untuk memperkecil ancaman

\section{KESIMPULAN}

Produk unggulan daerah berdasarkan klasifikasi OVOP terdiri dari beberapa kategori yaitu kategori kualitas sangat baik untuk pasar ekspor, kategori kualitas baik untuk pasar dalam negeri/ nasional, kategori kualitas cukup baik dengan beberapa perbaikan untuk pasar nasional/dalam negeri, kategori kualitas perlu bimbingan dasar namun bisa mencapai pada kualitas baik, kategori kualitas banyak kelemahan dan sulit untuk dikembangkan dalam waktu dekat. Untuk Wajik tapai Melayu termasuk produk unggulan daerah karena termasuk kategori kualitas baik dan memiliki ciri khass dan keunikan tersendiri.

\section{UCAPAN TERIMA KASIH}

Terima kasih kepada Kementrian Riset, Teknologi, Dan Pendidikan Tinggi - DIKTI yang telah mendanai kegiatan Pengabdian Kepada Masyarakat melalui Program Produk Unggulan Daerah pada tahun 2019.

\section{DAFTAR PUSTAKA}

[1] Peraturan Menteri Dalam Negeri Nomor 9 tahun 2014 Tentang Pedoman Pengembangan Produk Unggulan Daerah.

[2] Muhammad Tommy Fimi Putera (2015), Kajian Analisis One Village One Product (OVOP) di Kabupaten Paser

[3] Irawan Gani dkk (2018), Kajian Implementasi Konsep One Vilage One Product (ovop) di Kalimantan Timur, Jurnal Ekonomi Keuangan dan Manajemen INNOVASI Universitas Mulawarman Nomor ISSN On Line: 2528-1079 